\title{
Independence of children with Down syndrome: the experiences of families
}

\author{
Michelle Darezzo Rodrigues Nunes ${ }^{1}$ \\ Giselle Dupas²
}

This study develops a theoretical model concerning the experience of families of children with Down syndrome in preschool and school age. The frameworks used were Symbolic Interactionism and Grounded Theory. Semi-structured interviews were used as the instrument of investigation and ten families participated in the study. The Theoretical Model "Seeking the child's independence and autonomy through constant stimulation" was identified, which shows the family's efforts to enable the child to develop the best $\mathrm{s} /$ he can through stimulation in order to become less dependent in the future. This model can be used to facilitate interaction with the family and can be further expanded. Nurses should use spaces dedicated to care delivery to establish bonds with the family, and seek other spaces families frequent, to better meet their needs, since there are significant gaps in care and research addressing this population. Instead, they should be welcomed and seen as a partner in care delivery.

Descriptors: Down Syndrome; Family Nursing; Pediatric Nursing.

\footnotetext{
${ }^{1}$ RN, M.Sc. in Nursing. E-mail: mid13@hotmail.com.

2 RN, Ph.D. in Nursing, Professor, Departamento de Enfermagem, Universidade Federal de São Carlos, SP, Brazil. E-mail: gdupas@ufscar.br.
}

Corresponding Author:

Giselle Dupas

Universidade Federal de São Carlos. Departamento de Enfermagem

Rodovia Whashington Luis, SP 310, Km 235

CEP: 13565-905, São Carlos, SP, Brasil

E-mail: gdupas@ufscar.br 


\section{Independência da criança com síndrome de Down: a experiência da família}

O objetivo do trabalho foi desenvolver um modelo teórico sobre a experiência de famílias de crianças com síndrome de Down, em idade pré-escolar e escolar. Os referenciais utilizados foram o interacionismo simbólico e a teoria fundamentada nos dados. Utilizouse a entrevista semiestruturada consentida como instrumento de investigação, sendo que dez famílias participaram do estudo. Identificou-se o modelo teórico: buscando a independência e autonomia da criança através da estimulação constante, que mostra o esforço pelo melhor desenvolvimento da criança, através de estimulações, para um futuro menos dependente. Esse pode ser tomado como facilitador da interação com a família, com perspectivas de ser ampliado. O enfermeiro deve aproveitar espaços de atuação para estabelecer vínculo com a família, buscar os cenários predominantemente frequentados por ela, para melhor atender suas demandas, pois existem lacunas significativas de atenção e pesquisa junto a essa população, que precisa ser acolhida e tratada como parceira no cuidado.

Descritores: Síndrome de Down; Enfermagem Familiar; Enfermagem Pediátrica.

\section{Independencia del niño con síndrome de Down: la experiencia de la familia}

El objetivo del trabajo fue desarrollar un Modelo Teórico sobre la experiencia de familias de niños con síndrome de Down en edad pre escolar y escolar. Los marcos utilizados fueron el Interaccionismo Simbólico y la Teoría Fundamentada en los Datos. Utilizamos la entrevista semiestructurada como instrumento de investigación, siendo que diez familias participaron del estudio. Se identificó el Modelo Teórico: "Buscando la independencia y autonomía del niño a través de la estimulación constante", que muestra el esfuerzo por obtener el mejor desarrollo del niño a través de estimulaciones, para un futuro menos dependiente. Esto puede ser tomado como facilitador de la interacción con la familia, con perspectivas de ser ampliado. El enfermero debe aprovechar espacios de actuación para establecer vínculos con la familia, buscar los escenarios predominantemente frecuentados por ella, para atender mejor sus demandas, ya que existen lagunas significativas de atención e investigación junto a esta población, que precisa ser acogida y tratada como aliada en el cuidado.

Descriptores: Síndrome de Down; Enfermería de la Familia; Enfermería Pediátrica.

\section{Introduction}

Down Syndrome (DS) is a chronic condition caused by a chromosomal anomaly that occurs in an average of 1 out of each 700 to 800 live births. The most common health problems are: congenital heart disease, respiratory, visual and hearing problems; hypothyroidism; emotional and growth disorders. Most children with DS have moderate mental retardation and go through the normal phases of development, though more slowly. Early intervention is directly related to an increased gain in development ${ }^{(1)}$ and full family involvement.
The family that is composed of an organized set of people who relate and interact with each other and in which each member plays a specific role(2) can, through relationships established among its members, provide the child an environment conducive to growth and development ${ }^{(3)}$. Any alteration or change in one of the members can impact all the other family members. That is why when the health of any of a family's members is compromised, the family may enter into a crisis that disorganizes the family's structure ${ }^{(4)}$. 
Families of children with mental disabilities have an additional overload at all levels: social, psychological, financial and physical. Due to a marked concern with the child's development, the daily care provided to the child demands greater involvement from family members in the care provided over the long term and the impact of such care on the personal lives of family members. These factors can lead to a perception of limitations and restrictions that result from a prolonged and constant commitment to care ${ }^{(5)}$. In addition to such an overload, this situation can also trigger stress and depression, important aspects in the individual functioning of the family members because the effects of these conditions affect family dynamics, altering the relationships among its members ${ }^{(6)}$.

The birth of a child with DS impacts the entire family, evidencing the need to support its members, especially providing information and comforting them so they are able to find the best way to reorganize their family(7).

The child with a chronic condition demands much more time, dedication, and investment from the family than a child in a typical development process. Consequently, it is to be expected that nursing care provided to this family is differentiated from other care and helps the family to think about alternative ways to manage time dedicated to the care provided to the child, optimize resources related to expenditures, and organize actions taken in order to enhance family activities.

To understand how the family experiences such events is essential. What it causes in their lives, what their needs are, how the family defines the situation, are all items necessary to know so that nurses can gather tools to qualify the nursing care provided to these families. Hence, the objective of this study was to develop a Theoretical Model representative of the experience of families of children with DS.

\section{Method}

\section{Theoretical and methodological frameworks}

This is a qualitative study, whose theoretical framework is Symbolic Interactionism (SI). SI is a perspective that considers humans as beings who are: active beings in their environment; interact with others and themselves; dynamic beings; beings that define immediate situations according to both a developed and an altered perspective in social interaction in $\operatorname{progress}^{(8)}$. Grounded Theory (GT) was the methodological framework used, which allows one to generate theories based on data obtained and analyze them systematically and concomitantly with comparing data, from data collection to data analysis and vice-versa(9).

\section{Study procedures}

The study's participants were ten families of DS children who met the inclusion criteria: being preschool or school aged children and attending a Support Group including families of children with DS. We intended to study the experience of these families beyond the shock after the diagnosis, which is a very striking experience in the child's first years of life. Eight families were interviewed during data collection, totaling 21 participants. At least two family members participated in all the interviews, mostly the mother and father, but other family members were also present: grandmother, sister, and cousins. Most of the families were composed of a father, mother, child with DS and siblings. The educational level of the participants varied from completed primary school to a bachelor's degree. The children with DS were five to ten years old at the time of the interview, with an average age of approximately seven years old. The participants composed two groups with which we reached theoretical saturation of data. The families were randomly chosen from the support group list and from indications of the families themselves. We complied with the criterion age range while composing the groups. What distinguished both groups was the type of school: one group was composed of students from regular schools and students from special schools composed the other. A third group was composed of two families who validated the proposed Theoretical Model.

Data collection was conducted in the participants' households through semi-structured interviews guided by the following question: "What is it like for you to have a child with Down syndrome in the family?" Data analysis was concomitant with data collection. Constant comparative analysis was carried out following the steps recommended by the theoretical framework, which were: open coding, axial coding and selective coding(9).

The project was evaluated and approved by the Research Ethics Committee at UFSCar (process No. 280/2008) and all the participants and a witness signed free and informed consent forms.

\section{Results}

The experience of families with children with DS enabled us to generate the Theoretical Model: "Seeking the child's independence and autonomy through 
constant stimulation" (Figure 01), which originates from a methodological study performed with data, organized in codes, subcategories, categories and phenomena according to the paradigmatic model recommended by the framework. We opted to present the Model per se in this paper. Figure 1 presents the main categories that support it. The names of the categories are presented in italics throughout the text.

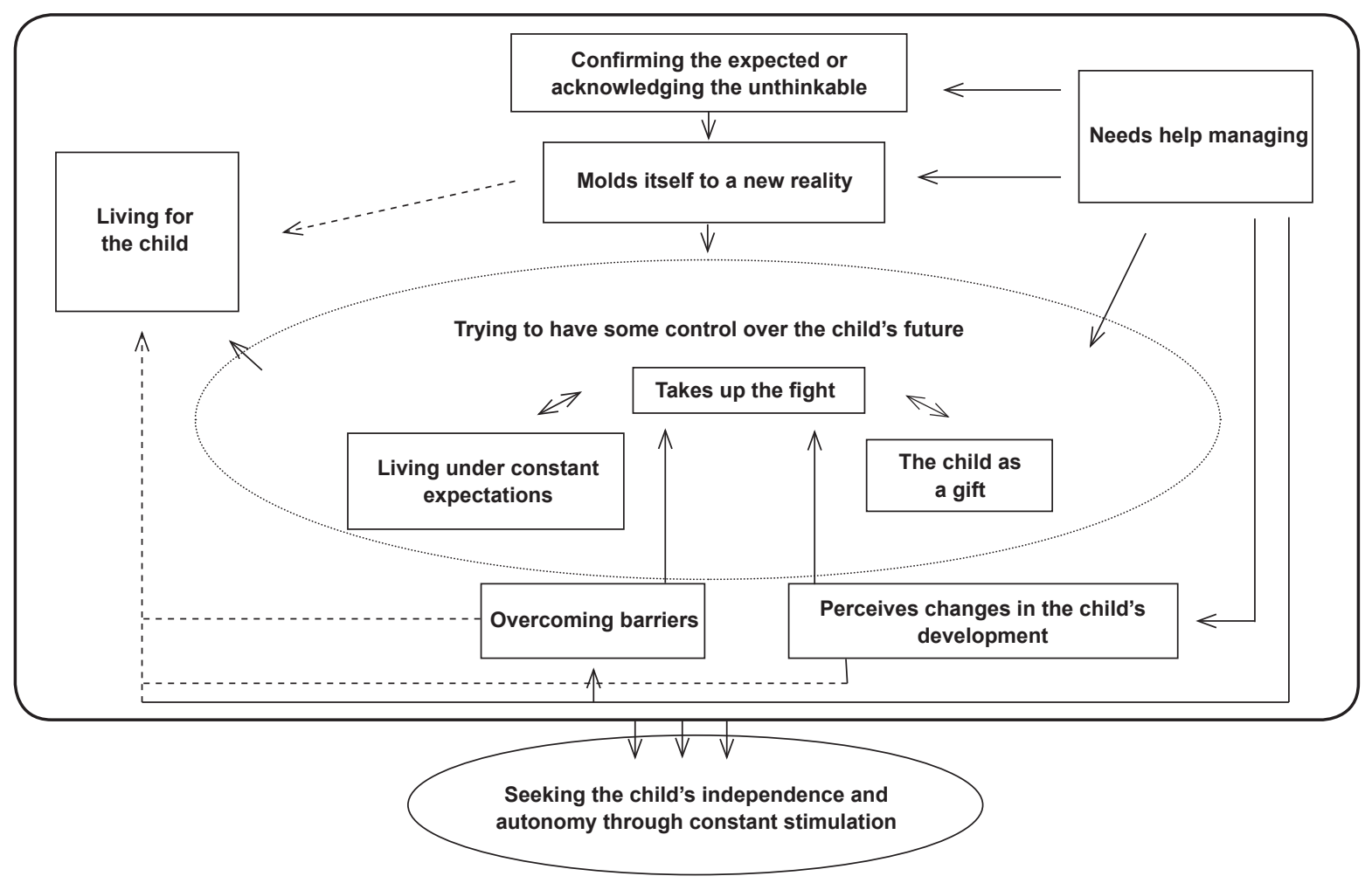

Figure 1 - Theoretical Model: Seeking the child's independence and autonomy through constant stimulation

Constructing the Theoretical Model: "Seeking the child's independence and autonomy through constant stimulation", portrays the continual pursuit of the family to enable the child to develop and have a future less dependent on others after the parents' death. The family is motivated by the unconditional love they have for the child and through a continuous effort without limits with which they attempt to develop the child's skills to the greatest extent possible.

$H e^{\prime l l}$ be always stimulated, knowledge will be always passed to him, always (mother 8 )

During such an experience, the family has moments of joy and satisfaction and also moments of uncertainly and difficulties in the face of the unknown: there is no certainty about what is coming. The first uncertainty occurs when the child is born and the family, confirming the expected or acknowledging the unthinkable, faces the unimaginable, that is, an unknown syndrome whose future is ignored. This event is usually accompanied by various feelings such as: impact/shock of the unexpected, surprise, doubt and sorrow, among others, characterized by the sensation the family is collapsing. The diagnosis introduces a lot of expectations as to how the child will grow and develop and the family sees itself experiencing a new event. Even when the family has some previous knowledge of DS or after acquiring such knowledge, the beginning is characterized by anguish due to a lack of parameters, which indicates the need to learn what to do.

...it was difficult when she was born. When she came it was something new. We didn't even know what Down syndrome was (father 2a).

Theoretically you know how "non-special" children develop... but what about a special child with Down Syndrome, what are the parameters of growth and development? When is she supposed to raise her head, to do this and that? (mother 1 ).

Right after birth the family needs to learn about DS and adapt the family routine to better care for the child and mold itself to new reality. At the beginning many questions emerge: what is DS? What to do now? Where to take the child? What is offered to the child and family? Over time the needs change according to each 
new development phase that the child goes through. Constant learning is required.

As he was growing up, when he started to scoot, he wouldn't crawl, I had to learn what to do to stimulate him, because physical therapy was only once a week... I had to do it at home also, had to learn it also. We learn everything to help him. And now... his behavior, because he's so aggressive... he does not accept instructions, has no limits, you have to learn how to deal with that also. (mother 3).

The families also experience many obstacles when the child's development does not occur as expected, thus the family perceives alterations in the child's development.

He still has no notion of what he's doing, he's seven but he's still like a little child... He used diapers less than 2, 3 weeks ago. He doesn't know to control, to use the toilet or ask to use the toilet, he feels like pooping and he poops wherever he is, then he passes his hand on it and puts his hand on wherever he is. [mimics the child and passes hand on the wall] (father 3 ).

In order to help the child to develop the most s/ he can, the family imposes on itself the need to learn how to cooperate more, to stimulate the child more to develop, seeking the best for her/his future. For the child to develop and overcome his/her own barriers, the family mobilizes and takes up the fight, seeks all kinds of treatments (speech and language therapy, physical therapy, psychologist, pedagogue...) trying to find services and professionals to efficiently care for the child and also seeks knowledge to be able to provide such stimuli at home.

...Today, we have like everything we have sought for her, speech and language therapist, psychologist, therapy, at the beginning there was physical therapy... You have to seek, to seek what is best for them, what helps the child to develop, stimuli has to be provided. We even enrolled her in ballet classes, swimming classes... (father $2 \mathrm{a}$ ).

The family also takes the child to physicians to investigate whether there is any associated health problem, which they need to find out. Time presses on the family as it tries to surpass itself and do its best, believing the child has prospects for the future. The family feels responsible for seeking knowledge to act; to provide stimuli early on, avoid wasting time, taking the child to medical appointments; to keep providing stimuli at home, interacting as much as possible; to be sensitive to detect potential changes in the child's health; to choose the best school. It believes that by assuming and carrying out these responsibilities the family will ensure, through a gradual acquirement of skills, the child's success and/or at least ensure the child is less dependent in the future. It is a responsibility and an exacerbated concern with the child's wellbeing, in doing everything possible, since theoretically, other children do not need such constant and intense follow-up. Hence the family sees the child as a great responsibility. Each of the actions to be carried out is complex for the family because it has to learn how to deal with it. Everything is different, atypical and more specific.

It is a sense that you have a great responsibility (...) of knowing that these first years of life depend on you, of being there to provide stimuli, to continue stimuli at home, to keep an eye open to perceive any changes and detect them in time (mother 1 ).

In order to offer everything the child needs, the family realizes it needs help to manage, both financial help, due to increased expenditures with the child's needs, and emotional help, to cope with difficult situations. The family members invest their time, attention and money providing diverse treatments to the child.

I guess that the greatest difficulty at the beginning was money, we had to pay for everything. But thank God, I have a friend, we say that is a friend, who you can count on, who helped me a lot. The family, my father-in-law, my mother-in-law helped a lot (father $2 \mathrm{~b}$ ).

...the parents have to make it work, you have to make it work, if you don't have money, you have to lose your pride, and go and ask for help (father 5) When my child started to go to this speech and language therapist, who is not paid by our health insurance, (...) I told my community that I had no means to pay her, that it was not cheap and a couple said: 'We will help you pay for the therapist' and they help 'til today (mother 5).

Among the sources of help, the exchange of experiences with other families reduces doubts because such exchange is a source of information, provides comfort and enables contact with other similar experiences; health professionals suggest solutions for difficult moments; friends and family members provide support; religiosity and faith provide strength and hope.

When I got home with [the child], I had a friend who had a child with DS, she offered to come here to my home, brought her child, gave me the idea of decorating the bedroom, told me what I was supposed to do at bath time, told me that all that fear would go away, that I didn't need to feel desperate. She said 'relax, don't keep thinking about this' (...) so it helped me a lot (...) It was worth it, she came here twice, she helped me a lot (mother 5).

Living for the child, the family sets aside its own needs and personal desires given the child's schedule.

...then you know, you nullify yourself. I can't do a lot of things, like going to the gym and leave him with his siblings. 
It's not something I can usually do. So, you can't have your own schedule, everything you do you have to think: 9am he has speech therapy, 10am he has OT and 11am he has to get ready for school. So, everything works around him, according to his schedule (mother 8).

It is dedication without measuring the effort, seeking the greatest degree of independence and autonomy the child is able to achieve.

I wish he could at least do the basics by himself. Take a shower, prepare food, eat, leave home, do the groceries, do something. Learn how to write and read, because when you know how to write and read, you acquire some independence. I guess. Not having to depend on someone or to have someone with him always. I wish he knew a bit about what is right and wrong (mother 3 ).

... he'll manage to have an occupation, a job, to be able to deal with money, or he'll have a place where he arranges things, he'll do things by himself and won't need others to do things for him. Or he'll put someone to do things, so he'll know and say 'I'll pay for you to do this for me' like non-special people do (mother 1 ).

The family lives the entire time concerned with the child's future, living under constant expectation. Will s/ he develop well? Will s/he be independent/autonomous? Who will help her/him when the parents are no longer there? There are many uncertainties, though the responsibility to help the child develop as much as possible helps the family to overcome all difficulties. Because the parents need to raise the child for a life and future that is unknown, they have to stimulate her/him extensively so that the child is able to be as independent as possible. Because they do not know whether the child will be self-sufficient or will be supported by others, the parents seek to identify people more connected to their cause in the family itself and draw closer to them so the child will be able to count on these individuals when the parents are no longer there. They act while thinking in terms of strategy, trying to have some control over the child's future, and positively intervene in it.

...we don't know about tomorrow, we may (die) tomorrow or sometime after... So, who'll care for him? She [daughter] is the youngest. And our concern is with tomorrow, how is he going to take care of himself if he doesn't have his father and mother anymore, so we try to do whatever we can for him (father 3).

Despite the difficulties, the family sees itself overcoming barriers and beating obstacles of living with the syndrome every time they see the child is developing and the family is adapting.

...I thought he'd have difficulties learning how to use the toilet, when he'd have to learn how to pee. And, on the contrary, when we least expected it, he used the toilet (...) he goes by himself, and I thought that he'd have problems with toilet training, but no, it was easier than with my daughter (cousin 5).

Additionally, the love and joy the child brings to the family is a great motivation. The family receives much in exchange for its efforts, through the child's positive characteristics (joy, affection, humility, good mood, detachment from material things, no prejudice) and for the opportunity the family has to learn with the child, perceiving the child as a gift.

The [child] is a delight, she brings so much joy to us, we are very proud of her, we introduce her without thinking 'they'll say she has deficiencies, that she has DS'. We introduce her thinking people will say she is beautiful 'they'll say she's smart' because this is what we think of her (mother 4).

\section{Discussion}

The birth of a child with DS strongly impacts the family, especially the mother and father, possibly generating stress, difficulties adapting, and imposing restrictions on the family ${ }^{(10)}$. Difficult moments arise from a chronic condition. The care provided to the child demands energy, time, deprives the family of privacy and may cause social and emotional isolation(2). The feelings accruing from the DS diagnosis in the studied families were: surprise, shock, anguish, grief and sadness, which agrees with those previously mentioned.

As reported in this study, the circumstance in which the diagnosis is disclosed is relevant and affects the feelings family members experience. Studies identify the inappropriate way news is usually given to the family. In addition to striking facts to be revealed to parents, especially when the mother is alone, information is provided in an incorrect manner and at an inopportune time. The information provided is pessimistic, limited, and does not provide necessary explanations, leaving the family anxious when they have to cope with the new situation, harming the establishment of bonds with the child and hindering the family in overcoming mourning for the expected child(4,11-15). Hence, health professionals need to be prepared to provide precise information concerning the syndrome, including information related to the possibilities of the child's development, helping the parents to overcome difficulties and encouraging them to seek the best conditions for fostering the child's growth and development ${ }^{(12-15)}$.

Another important aspect involving the experience of the family is a lack of knowledge concerning the syndrome among the general population. People seldom 
learn anything about it and have restricted knowledge concerning certain observable characteristics in individuals with DS; people feel insecure and helpless in the face of such a case in the family and have difficulties when taking the child home, given their limited knowledge. Additionally, this lack of information and guidance hinders the family's acceptance and action(4). The reports show that most families do not even know what DS is. There are situations in which the family has a significant need for care; there are opportunities for nurses to implement actions. Nurses need to be attentive to such situations, because difficult moments go beyond those experienced at the moment of diagnosis disclosure, such as: the family's lack of knowledge and information; lack of preparedness on the part of health professionals to provide such knowledge and information; need for social support and a support network; difficulties faced with the child's development, and prejudice. These are situations that alter the family's feelings, leave it worried, afflicted and anxious, revealing the need for nurses to help to change such a context.

Even though the presence of a child is a source of motivation and learning about the issue, health professionals play a very important role jointly with these families providing information and clarifying doubts, as well as promoting bonds with the child(4,1213,16-17). This is a role that health professionals cannot set aside and they can provide better assistance when the objective is to strengthen the family in the development of coping strategies and to support them to provide better care to the child, since the earlier the child receives stimuli the earlier s/he achieves advanced stages of neuropsychomotor development(18-19). The families with whom we talked measured no effort as too great to provide such stimuli.

The development of intelligence in children with DS does not depend only on genetic changes but also on important influences and situations in the child's environment that enable her/his development(15). Hence, cognitive and motor skills can develop rapidly and in a surprising way as long as these are trained and become part of the social life of children with $\mathrm{DS}^{(12)}$. Such a fact, once more, highlights the important role health professionals play with these families: that of clarifying their concerns and encouraging them to provide appropriate stimuli early on, which does not mean only providing access to devices and specialized professionals $^{(4)}$ but also to continue providing these stimuli at home and at school so children socialize outside of home as well(20).
Given the great responsibility of helping the child develop, most families totally modify their routines and live for the purpose of caring for the child, blanking out their desires and leaving behind many of their dreams. The child's high level of dependency in the performance of daily tasks such as walking, eating and using the toilet, impose heavy physical, psychological and social demands on mothers(16). The concern for the child's motor development is related to apprehension about the future because if the child's motor difficulties are not overcome, they will probably become even greater later on ${ }^{(21)}$.

When a woman has children, the care provided to them usually falls on her and when there is a child with disabilities, who demands even more attention, reconciling home labors with work is even more difficult(17). When the father has an effective participation in the child's follow-up, he allows the mother to share care provided to the child and also to care for herself. Hence, health professionals should be sensitive to opportunities of involving the father and other family members to share the workload, increasing and encouraging healthy intrafamily communication and contributing to re-establish its balance ${ }^{(7)}$. The care provided to the children from the studied families is usually centered on the mother, and actions aimed to share care with other family members are essential.

The concern with the child's future is also observed in other studies ${ }^{(16,22)}$; near and distant futures populate the thoughts of family members since the performance of the child in adult life is seen as something unpredictable and uncertain, leading mothers to become anxious and to feel anguish(17). Authors of a study with siblings of children with DS found that most of the participants will be responsible for the child with DS in the future, replacing the parents ${ }^{(12)}$. Among other strategies is the parents' desire to leave some financial support for the child to be used after they die, though they acknowledge the impossibility of doing this given their current financial situation ${ }^{(22)}$. The studied participants mentioned both the possibilities as potential strategies for the future.

The considerable change that occurs in the life of the family after the birth of a child with disabilities causes physical and emotional exhaustion, in addition to economic expenditures, that affect social life(22). The studied families reported they needed help coping with the child's demands and resulting difficulties. Such help can be provided by health professionals, religion and faith, and through the exchange of experiences. In another study addressing the needs of families of 
children with DS, the parents emphasized the lack of an appropriate space to talk and express their needs, anguish and doubts and report the importance of emotional support(11). Religion and spirituality also offer important support for the family members as sources of comfort and hope. Daily practices such as praying, being in contact with nature, having faith in a Superior Power all provide tranquility, wellbeing and strengthen life ${ }^{(23)}$.

Exchanging information with other families is also very relevant. Families identify specific situations in this process: those in which they need to listen, learn, obtain information, get counseling, which generally occurs after the disclosure of the diagnosis or when they experience new situations; and there are also situations when they feel more secure, willing to help, to provide information, and share their knowledge with those who are experiencing what they had already once experienced. Other authors corroborate this when they say that parents, after a period of receiving guidance and living with the child, perceive themselves as being able to talk with other families who are experiencing the situation. They feel responsible for the benefits they have received and feel they should help those in need(11).

The family feels rewarded when it perceives that the difficulties experienced are overcome and that their efforts were not in vain ${ }^{(24)}$. Since most of the development and growth of individuals with DS is due to the stimuli provided by the family and school, this creates a conducive environment for them to socialize and get involved with different people(20). The studied families celebrate their children's progress with joy and enthusiasm, each small of achievement of their children, which is the result of their efforts and much dedication.

The ability to adapt to a new routine was observed among families with children with DS; they believe that the experience resulted in positive consequences both individually and for the family as a whole(25). Another positive aspect is the fact that the parents feel blessed for having a child with disabilities, love this child unconditionally and find her/him to be wonderful(22). The mobilization of the family members to help the child to develop imposes restrictions and causes them to give some things up in favor of the child. The impact on the family functioning leads us to predict that the families' experiences will be only characterized by misgivings. Data, however, indicate that the love and joy the child inspires makes the experience to be a full one, an experience of overcoming.

Nurses have an important role in promoting the adaptation of families of children with DS, as they recognize and value the natural skills of the family to bear burdens, survive and prosper, even in the face of increasing challenges associated with a child with $\mathrm{DS}^{(25)}$.

\section{Final considerations}

The Theoretical Model presented here is an instrument that can enable nurses to understand the experience of families of children with DS and can be used to facilitate interactions. However, it is not limited to these components and can be enlarged as other findings can be added to the understanding of such a context. The need to qualify nurses to provide appropriate care and support families is highlighted. Spaces of professional practice should be used to establish bonds with the family, but new places for families to meet in addition to the hospital environment should be sought, such as places predominantly patronized by families, for example, rehabilitation outpatient clinics, in order to better know and heed these families' demands. This study revealed there is a significant gap in Brazilian nursing studies addressing this population. Further research addressing the issues identified here is suggested, such as: social support and support networks for families of children with DS; the relationship between the idealized future prospects and actual achievements; positive aspects that result from living with a child with DS; family health in view of what they have to give up, in addition to various other aspects. This study's limitations are the children's ages and the composition of the studied families, which may limit the results reached in this Theoretical Model.

\section{References}

1. Sobrinho JG, Golçalvez MJR, Soutinho MEP. Atenção à criança e ao adolescente com síndrome de Down. In: Santoro JR, organizador. Ecologia e desenvolvimento humano. São Paulo (SP): FUNPEC; 2008.

2. Elsen I, Marcon SS, Silva MRS, organizadores. O viver em família e sua interface com a saúde e a doença. 2a. ed. Maringá (PR): Eduem; 2004. 460 p.

3. Pereira-Silva NL, Dessen MA. Deficiência mental e família: implicações para o desenvolvimento da criança. Psicol Teor Pesqui. 2001;17(2):133-41.

4. Sunelaitis RC, Arruda DC, Marcon SS. A repercussão de um diagnóstico de síndrome de Down no cotidiano familiar: perspectiva da mãe. Acta Paul Enferm. 2007;20(3):264-71.

5. Shapiro J, Blacher J, Lopez SR. Maternal reactions to children with mental retardation. In: Burack JA, Hodapp RM, Zigler E. Handbook of mental retardation and development. Cambridge: Cambridge University Press; 1998. p. 606-36. 
6. Pereira-Silva NL, Dessen MA. Padrões de interação genitores-crianças com e sem síndrome de Down. Psicol Reflex Crit. 2006;19(2):283-91.

7. Luiz FMR. Experiências de famílias de crianças com síndrome de Down no processo de inclusão na rede regular de ensino [dissertação de mestrado]. Ribeirão Preto (SP): Escola de Enfermagem de Ribeirão Preto da Universidade de São Paulo; 2009. 116 p.

8. Charon JM. Symbolic interacionism: an introduction, an interpretation, an integration. 9th. ed. Englewood Cliffs (NJ): Prentice Hall; 2007. 241 p.

9. Strauss A, Corbin J. Pesquisa qualitativa: técnicas e procedimentos para o desenvolvimento da teoria fundamentada. 2nd. ed. Porto Alegre (RS): Artmed; 2008. 288 p.

10. Henn CG, Piccinini CA, Garcias GL. A família no contexto da síndrome de Down: revisando a literatura. Psicol Estud. 2008;13(3):485-93.

11. Colnago NAS, Alves ZMM. Orientação familiar para pais de crianças com síndrome de Down. Rev Extensão Pesqui Educ Saúde. 2004;2:11-29.

12. Iervolino AS. Estudo das percepções, sentimentos e concepções para entender o luto de familiares de portadores da síndrome de Down da cidade de SobralCeará [tese de doutorado]. São Paulo (SP): Faculdade de Saúde Pública da Universidade de São Paulo; 2005. $276 \mathrm{p}$.

13. Lemes LC, Barbosa MAM. Comunicando a mãe o nascimento do filho com deficiência. Acta Paul Enferm. 2007;20(4):441-5.

14. Martins DA, Polak YNS. Cuidando do portador de síndrome de Down e seu significante. Ciênc Cuidado Saúde. 2002;1(1):111-5.

15. Voivodic MAMA, Storer MRS. O desenvolvimento cognitivo das crianças com síndrome de Down à luz das relações familiares. Psicol Teor Prat. 2002;4(2):31-40.

16. Lam M, Mackenzie AE. Coping with Down syndrome. Qual Health Res. 2002;12(2):223-37.

17. Sigaud CHS, Reis AOA. A representação social da mãe acerca da criança com síndrome de Down. Rev Esc Enferm USP. 1999;33(2):148-56.

18. Carswell WA. Estudo da assistência de enfermagem a crianças que apresentam síndrome de Down. Rev. Latino-Am. Enfermagem. 1993;1(2):113-28.

19. Hallal CZ, Marques NR, Braccialli LMP. Aquisição de habilidades funcionais na área de mobilidade em crianças atendidas em um programa de estimulação precoce. Rev Bras Crescimento Desenvolv Hum. 2008;18(1):27-34.
20. Ramos AF, Caetano JA, Soares E, Rolim KMC. A convivência da família com o portador de Síndrome de Down à luz da Teoria Humanística. Rev Bras Enferm. 2006;59(3):262-8.

21. Pereira-Silva NL, Dessen MA. Crianças com e sem síndrome de Down: valores e crenças de pais e professores. Rev Bras Educ Espec. 2007;13(3):429-46. 22. Sari HY, Baser G, Tura JM. Experiences of mothers of children with Down syndrome. Paediatr Nurs. 2006;18(4):29-32.

23. Dezorzi LW, Crossetti MGO. A espiritualidade no cuidado de si para profissionais de enfermagem em terapia intensiva. Rev. Latino-Am. Enfermagem. 2008;16(2):212-7.

24. Oliveira I, Angelo M. Vivenciando com o filho uma passagem difícil e reveladora: a experiência da mãe acompanhante. Rev Esc Enferm USP. 2000;34(2):202-8.

25. Van Riper M. Families of children with Down syndrome: responding to "a change in plans" with resilience. J Pediatr Nurs. 2007;22(2):116-28. 